\title{
KOMPETENSI PEDAGOGIK GURU AGAMA KATOLIK SEKOLAH DASAR DI KABUPATEN BANTUL
}

\author{
I Wayan Setioka, Pardjono \\ Kantor Kementerian Agama Kabupaten Kulon Progo, Universitas Negeri Yogyakarta \\ iwayansetioka@gmail.com, pardjono@uny.ac.id
}

\begin{abstract}
Abstrak
Penelitian ini bertujuan mengungkap: (1) kompetensi pedagogik guru agama katolik SD di Kabupaten Bantul, (2) mengetahui bagaimana kaitan latar belakang profil guru dengan kompetensi pedagogik guru agama katolik SD di Kabupaten Bantul. Penelitian ini menggunakan pendekatan kuantitatif jenis deskriptif. Penelitian ini dilakukan pada bulan November dan Desember 2013. Data dikumpulkan melalui angket isian pertanyaan dan tes. Populasi penelitian ini adalah 28 orang guru agama Katolik Sekolah Dasar di Kabupaten Bantul. Hasil analisis deskriptif menunjukkan bahwa: (1) kompetensi pedagogik guru agama katolik Sekolah Dasar di Bantul dalam kategori cukup; (2) latar belakang pendidikan belum berkontribusi meningkatkan kompetensi pedagogik guru; (3) latar belakang masa kerja menjadi guru belum berkontribusi meningkatkan kompetensi pedagogik guru; (4) tingginya pangkat golongan ruang belum berkontribusi meningkatkan kompetensi pedagogik guru agama katolik SD di Bantul; (5) latar belakang pendidikan, lamanya masa kerja, pangkat golongan ruang guru, belum berkontribusi meningkatkan kompetensi pedagogik guru agama katolik SD di Kabupaten Bantul.
\end{abstract}

Kata Kunci: Kompetensi pedagogik, latar belakang guru

\section{THE PEDAGOGIC COMPETENCY OF CHATOLIC RELIGION ON ELEMENTARY SCHOOL OF BANTUL REGENCY}

\author{
I Wayan Setioka, Pardjono \\ Kantor Kementerian Agama Kabupaten Kulon Progo, Universitas Negeri Yogyakarta \\ iwayansetioka@gmail.com, pardjono@uny.ac.id
}

\begin{abstract}
This research is aimed to: (1) reveal the pedagogic competency of chatolic religion on elementary school of Bantul regency, (2) know the relationship between the profile background of teacher with the the pedagogic competency of chatolic religion on elementary school of Bantul regency. This reasearch was carried out on November and December 2013. The collecting data technique used is questionnaire and test. It is a research of quantitative descriptive. The population of the research is all teachers of chatolic religion on elementary school in Bantul regency. There are 28 teachers of chatolic religion on elementary school in Bantul regency. The descriptive analysis shows that: (1) the pedagogic competency of chatolic religion on elementary school of Bantul regency is in the category adequate or satisfactory; (2) the education background does not automatically enhance pedagogic competency, (3) the background of long working period does not automatically contribute to the pedagogic competency; (4) the level of position does not automatically contribute to the pedagogic competency of catholic teachers of elementary school in Bantul regency, (5) the education background, the working period, the working position rank do not automatically enhance the pedagogic competency of catholic teachers in Bantul regency.
\end{abstract}

Keywords: pedagogic competency, the teacher background 


\section{Pendahuluan}

Perkembangan dan kemajuan zaman di pelbagai bidang, khususnya tuntutan mutu pendidikan di era global, di tengah pelaksanaan Otonomi Daerah, menyebabkan adanya perubahan tatanan. Adanya tuntutan profesional dalam aneka perspektif sosial, ekonomi, teknologi, pendidikan, dan kemanusiaan, selalu mempersyaratkan kemampuan yang diperlukan orang untuk melakukan aneka pekerjaan semakin meningkat. Dalam bidang pendidikan, jabatan guru merupakan jabatan profesional yang menghendaki guru harus bekerja secara profesional. Bekerja sebagai seorang profesional berarti bekerja dengan keahlian, dan keahlian hanya dapat diperoleh melalui pendidikan khusus (Hamsah, 2007, p.42). Guru sebagai jabatan profesional dapat dijelaskan sebagai berikut: Pendidik merupakan tenaga profesional yang bertugas merencanakan dan melaksanakan proses pembelajaran, menilai hasil pembelajaran, melakukan pembimbingan dan pelatihan, serta melakukan penelitian dan pengabdian kepada masyarakat, terutama bagi pendidik pada perguruan tinggi (UU RI No. 20 Tahun 2003, Sisdiknas Pasal 39 ayat 2). Guru sebagai tenaga profesional merupakan tenaga kependidikan yang berkualifikasi pendidikan sekurang-kurangnya Strata Satu (S1) atau yang setara, dan memiliki wewenang penuh dalam perencanaan, pelaksanaan, penilaian, dan pengendalian pendidikan/pengajaran. Efektivitas proses pembelajaran di kelas, sangat ditentukan oleh kompetensi guru, disamping faktor lain, seperti anak didik, lingkungan dan fasilitas (Sudarwan, 2002, p.30).

Guru sebagai jabatan profesional, sekurang-kurangnya memiliki kompetensi: Kompetensi pedagogik, kompetensi kepribadian, kompetensi sosial,dan kompetensi profesional (UU RI No. 14 Tahun 2005). Kompetensi pedagogik adalah kemampuan guru dalam mengelola pembelajaran peserta didik. Kompetensi kepribadian adalah kemampuan kepribadian yang mantap, berakhlak mulia, arif dan berwibawa, serta menjadi teladan peserta didik.Kompetensi sosial adalah kemampuan guru untuk ber- komunikasi dan berinteraksi secara efektif dan efisien dengan peserta didik, sesama guru, orang tua/wali peserta didik dan masyarakat sekitar. Sedangkan kompetensi profesional adalah kemampuan penguasaan materi pelajaran secara luas dan mendalam.

Guru pendidikan agama Katolik adalah tenaga profesional yang dalam tugasnya membantu orang tua murid dalam rangka membina iman anak.Tugas orang tua murid memberikan pendidikan dasar dan menjadi pendidik utama bagi anakanak di dalam keluarga. Pendidikan yang diwariskan orang tua dan yang dikembangkan di dalam keluarga haruslah pendidikan dalam arti yang menyeluruh, yang meliputi pendidikan fisik, kepribadian, intelektual, sosial, iman, dan moral (Konferensi Waligereja Indonesia, 1995, p.22).

Balitbang Depdiknas (2010) menyebutkan dari sekitar 1,2 juta guru SD/MI hanya $13,8 \%$ yang berpendidikan diploma DII kependidikan ke atas, sekitar 680.000 guru SMP/MTs baru 38,8\% yang berpendidikan DIII kependidikan ke atas. Di tingkat sekolah menengah dari 337.5 guru baru $57,8 \%$ yang memiliki pendidikan S1 ke atas. Di tingkat pendidikan tinggi dari 181.544 dosen, baru $18,86 \%$ yang berpendidikan S2 ke atas dan hanya 3,48\% berpendidikan S3. Hal ini menunjukkan bahwa sebagian guru Sekolah Dasar tidak layak mengajar atau tidak memiliki kualifikasi kompetensi yang diprasyaratkan, termasuk di dalamnya guru agama katolik.

Permasalahan lain yang dihadapi yaitu semakin kekurangan tenaga pendidik yang berkualitas tinggi, memiliki sarana, dan prasarana yang memadai (Konferensi Waligereja Indonesia, 1995, p.62). Sudah ada usaha membantu guru agar lebih mampu mengajar, melalui pelbagai penataran dan perubahan kurikulum. Namun yang masih senantiasa diperlukan adalah peningkatan mutu guru sebagai pendidik dan perhatian proporsional kepada guru dari pihak siswa, orang tua siswa, pengelola sekolah, pemerintah, serta masyarakat. Konsekuensinya guru pendidikan agama Katolik dituntut memiliki kompetensi 
sebagai suatu tuntutan untuk menjadi profesional.

Secara khusus Mukminan (Prasaja, 2009) pada seminar Hasil Penelitian, "Peta Kebutuhan Guru di Kabupaten Bantul 2009", menyatakan bahwa kualitas pendidikan sangat ditentukan oleh para pengelola dan pelaku pendidikan. Akan tetapi realitas di lapangan menunjukkan kompetensi profesional guru umumnya masih rendah, sistem keterjaminan mutu belum berjalan dengan baik, penyiapan guru sangat tertinggal dibandingkan kebutuhan untuk mengajar dengan cara dan pola padat teknologi, padat informasi, dan padat komunikasi.

Dengan diberlakukannya Undang Undang No. 20 Tahun 2003 tentang Sistem Pendidikan Nasional kedudukan guru menjadi sangat penting dan diminati masyarakat, serta sekaligus sebagai tantangan bagaimana dapat memberdayakan sumber daya pendidikan. Apalagi tingkat kesejahteraan guru melalui sertifikasi dan kesejahteraan lainnya menjadi profesi yang menjanjikan. Hal tersebut ditunjukkan dengan semakin banyaknya minat mahasiswa untuk kuliah di bidang kependidikan.

Berdasarkan latar belakang masalah tersebut, maka dapat kami identifikasikan masalah-masalah sebagai berikut: (1) tuntutan mutu pendidikan di era global tidak sejalan dengan sumber daya pendidikan yang ada; (2) guru pendidikan agama Katolik belum bekerja secara professional; (3) karir guru dengan golongan IVa belum bisa berkembang sesuai dengan tuntutan dan regulasi yang ada; (4) profesi guru sebagai tenaga profesional memprasyaratkan pendidikan minimal Strata Satu (S1) akan tetapi tidak semua guru memiliki kualifikasi tersebut; (5) belum dipenuhinya kualifikasi dan kompetensi guru Pendidikan Agama Katolik Sekolah Dasar di Kabupaten Bantul menyebabkan rendahnya mutu pengajaran Pendidikan Agama Katolik; (6) kompetensi Pedagogik Guru Agama Katolik Sekolah Dasar di kabupaten Bantul belum dikelola dengan maksimal, sehingga menyebabkan rendahnya mutu pendidikan.
Setelah melakukan kajian umum atau studi pendahuluan, maka dalam penyajian ini difokuskan pada: (1) diskripsi Kompetensi Pedagogik khususnya pada kompetensi pedagogik Guru Agama Katolik Sekolah Dasar di Kabupaten Bantul; (2) kaitan Latar Belakang Profil Guru dengan kompetensi pedagogik guru pendidikan Agama Katolik Sekolah Dasar di Kabupaten Bantul.

Tujuan penelitian ini adalah untuk mendeskripsikan kompetensi guru Agama Katolik di Kabupaten Bantul. Secara khusus penelitian ini bertujuan: (1) mendeskripsikan kompetensi pedagogik guru agama Katolik Sekolah Dasar di Kabupaten Bantul; (2) mengetahui bagaimana kaitan latar belakang profil guru dengan kompetensi pedagogik guru Agama Katolik Sekolah Dasar di Kabupaten Bantul.

Hasil penelitian diharapkan dapat memberikan sumbangan positif bagi penyelenggaraan Pendidikan Agama Katolik di Kabupaten Bantul, terutama nilai-nilai kemanfaatan: (1) untuk mengembangkan ilmu/ kegunaan teoritis. Sebagai informasi teoretik pengembangan manajemen sumber daya manusia, khususnya manajemen kompetensi pedagogik guru Pendidikan Agama Katolik Sekolah Dasar di Kabupaten Bantul. Mengaplikasikan teori manajemen pendidikan pada manajemen kompetensi pedagogik guru pendidikan Agama Katolik Sekolah Dasar di Kabupaten Bantul. (2) kegunaan praktis, yaitu sebagai bahan pertimbangan kebijakan, membantu memecahkan masalah-masalah yang dihadapi dalam pekerjaan.(a) dengan mengetahui kompetensi pedagogik guru agama Katolik Sekolah Dasar Kabupaten Bantul akan membantu dalam upaya pengembangan karir guru; (b) dengan mengetahui bagaimana kaitan latar belakang profil guru dengan kompetensi pedagogik guru agama Katolik Sekolah Dasar di Kabupaten Bantul diharapkan dapat diketahui peta keadaan guru serta solusi dalam mengatasinya.

\section{Metode Penelitian}

Penelitian ini menggunakan pendekatan kuantitatif jenis deskriptif. Statistik 
deskriptif adalah statistik yang berfungsi untuk mendiskripsikan atau memberi gambaran terhadap obyek yang diteliti melalui data populasi sebagaimana adanya. Pada statistik deskriptif dikemukakan cara-cara penyajian data, dengan tabel biasa maupun distribusi frekuensi, grafik garis maupun batang, penjelasan kelompok melalui modus, median, mean dan variasi kelompok melalui rentang dan simpangan baku (Sugiyono, 2010, p.207). Dalam penelitian ini menggunakan model tes untuk uji kompetensi pedagogik guru Agama Katolik Sekolah Dasar di Kabupaten Bantul dan tidak menggunakan model Penilaian Kinerja Guru (PKG).

Penelitian ini dilaksanakan pada guru agama Katolik Sekolah Dasar di Kabupaten Bantul pada bulan November dan Desember 2013. Alasan dipilihnya sebagai tempat penelitian adalah kemudahan tempat penelitian serta peneliti sudah memiliki hubungan yang baik dengan Pengawas Pendidikan Agama Katolik Sekolah Dasar di Kabupaten Bantul, sehingga memudahkan dalam perijinan ke sekolah dan pendekatan kepada guru. Pendekatan yang dipilih untuk memasuki tempat penelitian adalah pendekatan informal dan formal. Peneliti pertama-tama mengadakan pendekatan pribadi dengan Pengawas dan menentukan waktu pertemuan dengan guru untuk dilaaksanakan test kompetensi secara klasikal menggunakan kesempatan pertemuan rutin bulanan pertemuan Kelompok Kerja Guru (KKG). Disamping itu juga peneliti datang ke sekolah dimana guru melaksanakan tugas sebagai Guru Agama Katolik, untuk melengkapi data-data yang diperlukan.

Populasi pada penelitian ini adalah seluruh guru agama Katolik Sekolah Dasar di Kabupaten Bantul, baik yang berstatus sebagai guru Pegawai Negeri Sipil (PNS), Guru Tetap Yayasan (GTY) dan Guru Agama Katolik Tidak Tetap (GATT), yang berjumlah 28 orang. Semua populasi diambil sebagai sampel penelitian karena jumlah guru agama Katolik pada jenjang Sekolah Dasar semuanya berjumlah 28 orang.
Penelitian ini mengenai kompetensi pedagogik dan kaitan latar belakang profil guru dengan kompetensi pedagogik guru agama Katolik Sekolah Dasar di Bantul.(1) kompetensi pedagogik merupakan kemampuan guru dalam mengelola pembelajaran, sekurang-kurangnya meliputi: (a) memahami peserta didik dengan memanfaatkan prinsip-prinsip perkembangan kognitif; (b) memahami peserta didik dengan mendasarkan pada karakteristik masing-masing; (c) mengidentifikasi bekal ajar awal; (d) menerapkan teori belajar dan pembelajaran; (e) menerapkan strategi pembelajaran yang mendidik; (f) menyusun rencana pembelajaran; (g) menata latar/setting pembelajaran; (h) melaksanakan pembelajaran yang kondusif; (i) menentukan tingkat ketuntasan belajar; (j) menganalisis penilaian proses dan hasil belajar untuk menentukan ketuntasan belajar; (k) menggunakan informasi hasil belajar sebagai dasar pemberian balikan atau pengayaan; (1) memanfaatkan hasil penilaian untuk perbaikan kualitas pembelajaran; (m) memfasilitasi peserta didik untuk mengembangkan potensinya. (2) kaitan latar belakang profil guru dengan kompetensi pedagogik guru agama katolik SD Kabupaten Bantul. Sekurang-kurangnya meliputi: pangkat dan golongan pertama, pangkat golongan sekarang, jenis kelamin, usia, pendidikan awal menjadi PNS/ pegawai, pendidikan terakhir, tugas tambahan selain guru agama, ruang/ tempat mengajar agama Katolik, beban mengajar per minggu, kendaraan yang dipakai ke tempat kerja, jarak tempuh ke tempat kerja, masa kerja menjadi guru agama, dan pekerjaan sebelum menjadi guru agama. Teknik pengumpul data yang digunakan adalah angket isian pertanyaan berupa isian kuesioner dan test dalam bentuk soal pilihan ganda.

Instrumen penelitian harus memenuhi validitas dan reliabilitas. Untuk mendapatkan insrumen yang valid dan reliabel, dilakukan validasi oleh pakar (expert judgement) dan diujicobakan di lapangan. Validitas dilakukan merujuk pada derajat bukti empiris dan rasional teoritis yang mendukung ketepatan dan kesesuaian pe- 
nafsiran skor tes dan tindakan (Mardapi, 2008, p.16). Instrumen diujicobakan pada 25 orang responden dengan maksud untuk mengetahui kesahihan (validitas) dan tingkat keandalan (reliabilitas) instrumen tersebut. Uji coba instrumen dilakukan terhadap guru agama Katolik Sekolah Dasar di Kabupaten Kulon Progo.

Validitas instrumen yang dimaksud dalam penelitian ini adalah validitas isi (content) dan validitas konstruk. Pendekatan validitas konstruk dilakukan berdasarkan pendekatan rasional dan pendekatan empirik. Pendekatan rasional dilakukan dengan memperhatikan unsur-unsur yang membentuk konstruk. Selain itu diarahkan pada penetapan butir-butur sesuai dengan unsur-unsur yang terdapat pada konstruk tersebut. Pendekatan empiris dimaksudkan untuk menilai sejauhmana kesesuaian unsur-unsur di dalam instrumen dengan apa yang diramalkan dalam konstruk tersebut. Perhitungan validitas dalam penelitian ini dilakukan dengan menggunakan bantuan komputer program MS Excel for windows. Untuk menentukan ya tidaknya suatu butir atau item pertanyaan/pernyataan menggunakan kriteria menurut Sugiyono (2006, p.455) dengan $\mathrm{N}=25$ pada taraf signifikansi $5 \%$ adalah 0,361 . Butir pertanyaan/ pernyataan yang mendapat skor di atas kriteria tersebut $(0,361)$ dinyatakan valid sedangkan butir pertanyaan/pernyataan yang mendapatkan skor di bawah kriteria $(0,361)$ dinyatakan tidak valid dan gugur.

Instrumen kompetensi pedagogik guru terdiri atas 40 butir tes yang telah diujicobakan. Hasil analisis data uji coba yang dilakukan terdapat 6 (enam) butir soal yang tidak valid yaitu butir soal nomor 7, 13, 18, 32, 35, 39. Jadi tes kompetensi pedagogik yang digunakan untuk penelitian ada 34 butir soal. Secara keseluruhan hasil uji coba instrumen kompetensi pedagogik guru agama Katolik dapat di lihat pada Lampiran 3, 4, 5, 6 halaman 112, 113, 114, 115.

Reliabilitas tes berhubungan dengan konsistensi hasil pengukuran, yaitu seberapa konsisten skor tes dari satu pengukuran ke pengukuran berikutnya. Reliabilitas mengacu kepada konsistensi atau kepercayaan hasil ukur, yang mengandung makna kecermatan pengukuran. Reliabilitas instrumen pada penelitian ini merujuk pada rumus alpha yang dikemukakan Fernandes (1984, p.34) yaitu:

$$
\mathrm{r}=\left(\frac{k}{\mathrm{k}-1}\right)=\left(1-\frac{\sum \sigma_{1}^{2}}{\sigma 2}\right)
$$

Keterangan:

$\mathrm{r} \quad=$ Reliabilitas instrumen

$\mathrm{k}=$ Banyaknya butir pertanyaan

$\sum \sigma_{1}^{2}=$ Jumlah varians butir

$\sigma 2=$ Varians total.

Kriteria yang digunakan untuk menetapkan keterandalan instrumen adalah indeks kehandalan instrumen dengan formula Crombach-Alpha. Menurut Feldt \& Brennan (Mardapi, 2008, p.14) bahwa indeks kehandalan tes lebih besar dari 0,70 sudah dapat diterima. Perhitungan reliabilitas instrumen dilakukan dengan menggunakan bantuan computer program MS Excel for windows. Berdasarkan hasil analisis, diperoleh reliabilitas instrumen dari kompetensi guru, adalah 0,937. Tabulasi data untuk masing-masing variabel dilakukan terhadap skor yang telah diperoleh, dengan mempergunakan bantuan komputer seri program SPSS versi 15,0.

Data kuantitatif yang diperoleh dibandingkan dengan persentase perolehan skor setiap responden pada tiap kasus dengan kriteria penilaian. Besarnya persentase menunjukkan kategori informasi yang terungkap, sehingga dapat diketahui posisi masing-masing aspek dalam keseluruhan maupun sebagian aspek yang diteliti. Kriteria kecenderungan yang digunakan mengacu pada rumus yang dikembangkan dalam Peraturan Menteri Negara Pendayagunaan Aparatur Negara dan Reformasi Birokrasi, Nomor 16 Tahun 2009 tentang Jabatan Fungsional Guru Dan Angka Kreditnya. Dalam penelitian Kompetensi Pedagogik Guru Agama Katolik Sekolah Dasar di Kabupaten Bantul menggunakan kriteria penilaian komponen seperti pada tabel 3, nilai tes dikonversikan pada kriteria penilaian komponen dan tidak dikonversikan ke dalam angka kredit guru. 
Tabel 1. Kriteria Penilaian Komponen

\begin{tabular}{cc}
\hline Rentangan Skor & Kategori \\
\hline $0-50$ & Kurang \\
$51-60$ & Sedang \\
$61-75$ & Cukup \\
$76-90$ & Baik
\end{tabular}

91-100 Amat Baik

Sumber: Permenpan dan RB, Nomor 16 Tahun 2009

Nilai Kinerja Guru sebagaimana dimaksud pada Tabel 1 dikonversikan ke dalam angka skor yang harus dicapai sebagai berikut: (a) sebutan amat baik diberikan pada kelompok dengan rentang skor 91-100; (b) sebutan baik diberikan pada kelompok dengan rentang skor 76-90; (b) sebutan cukup diberikan pada kelompok dengan rentang skor 61-75; (c) sebutan sedang diberikan pada kelompok dengan rentang skor 51-60; (d) sebutan kurang diberikan pada kelompok dengan rentang skor 0-50.

Analisa data yang dipergunakan dalam penelitian adalah deskriptif. Data diklasifikasikan, diverifikasi dalam kelompok data, dan selanjutnya dianalisis, dicari rerata, median, mode, dan tabulasi serta ditarik kesimpulan.

\section{Hasil Penelitian dan Pembahasan}

Pada bab ini secara berturut-turut disajikan data kompetensi pedagogik guru agama Katolik Sekolah Dasar di Kabupaten Bantul serta kaitan latar belakang pendidikan, masa kerja, jabatan guru, dengan kompetensi pedagogik guru agama Katolik Sekolah Dasar di kabupaten Bantul, yang diperoleh melalui angket dan tes yang dirancang oleh peneliti berdasarkan indikatorindikatornya. Hasil analisis statistik, data variabel kompetensi pedagogik memiliki rentang skor antara 13,00 sampai 30,00. Hasil analisis dengan bantuan komputer seri program SPSS versi 15. Perolehan skor menunjukkan bahwa variabel kompetensi pedagogik memiliki rerata sebesar 21,67; simpangan baku sebesar 3,90; median sebesar 21,50; dan modus 19,00. Distribusi frekuensi dan persentase perolehan skor kompetensi pedagogik disajikan pada Tabel 2, 3, 4 .
Tabel 2. Analisis Data Kompetensi Pedagogik GAK

\begin{tabular}{lc}
\hline & Total Skor Kompetensi \\
\hline N Valid & 28 \\
Missing & 0 \\
Mean & 21,6786 \\
Median & 21,5000 \\
Mode & 19,00 \\
Standar Deviasi & 3,90682 \\
Minimum & 13,00 \\
Maksimum & 30,00 \\
\hline
\end{tabular}

Tabel 3. Analisis Data Kompetensi Pedagogik GAK

\begin{tabular}{ccccc}
\hline Valid & F & Persentase & Valid \% & Cum. \% \\
\hline 13 & 1 & 3,6 & 3,6 & 3,6 \\
17 & 2 & 7,1 & 7,1 & 10,7 \\
18 & 3 & 10,7 & 10,7 & 21,4 \\
19 & 4 & 14,3 & 14,3 & 35,7 \\
20 & 2 & 7,1 & 7,1 & 42,9 \\
21 & 4 & 7,1 & 7,1 & 50,0 \\
22 & 2 & 7,1 & 7,1 & 57,1 \\
23 & 2 & 7,1 & 7,1 & 64,3 \\
24 & 4 & 14,3 & 14,3 & 78,6 \\
25 & 2 & 7,1 & 7,1 & 85,7 \\
26 & 1 & 3,6 & 3,6 & 89,3 \\
27 & 1 & 3,6 & 3,6 & 92,9 \\
29 & 1 & 3,6 & 3,6 & 96,4 \\
30 & 1 & 3,6 & 3,6 & 100,0 \\
Total & 28 & 100,0 & 100,0 & - \\
\hline
\end{tabular}

Tabel 4. Analisis Data Kompetensi Pedagogik GAK

\begin{tabular}{lcccc}
\hline Valid & F & Persentase & Valid \% & Cum. \% \\
\hline Kurang & 3 & 10,7 & 10,7 & 10,7 \\
Sedang & 9 & 32,1 & 32,1 & 42,9 \\
Cukup & 12 & 42,9 & 42,9 & 85,7 \\
Baik & 4 & 14,3 & 14,3 & 100,0 \\
Total & 28 & 100,0 & 100,0 & - \\
\hline
\end{tabular}

Diketahui dari 28 orang guru agama Katolik Sekolah Dasar di Bantul ada 12 orang $(42,9 \%)$ dengan kompetensi pedagogik cukup, 9 orang $(32,1 \%)$ dengan kompetensi pedagogik sedang, 4 orang $(14,3 \%)$ dengan kompetensi baik, dan 3 orang $(10,7$ $\%)$ dengan kompetensi pedagogik kurang. Hal ini menunjukkan bahwa secara umum 
kompetensi pedagogik guru agama Katolik Sekolah Dasar di Bantul termasuk dalam kategori cukup yang ditunjukkan oleh persentase tersebar perolehaan skor tersebut. Diperoleh data bahwa kompetensi pedagogik guru agama Katolik berada pada kompetensi cukup dan sedang, sedangkan sisanya pada kompetensi baik dan kurang. Visualisasi kategori perolehan skor kompetensi pedagogik guru agama Katolik Sekolah Dasar di Bantul disajikan pada Gambar 1.

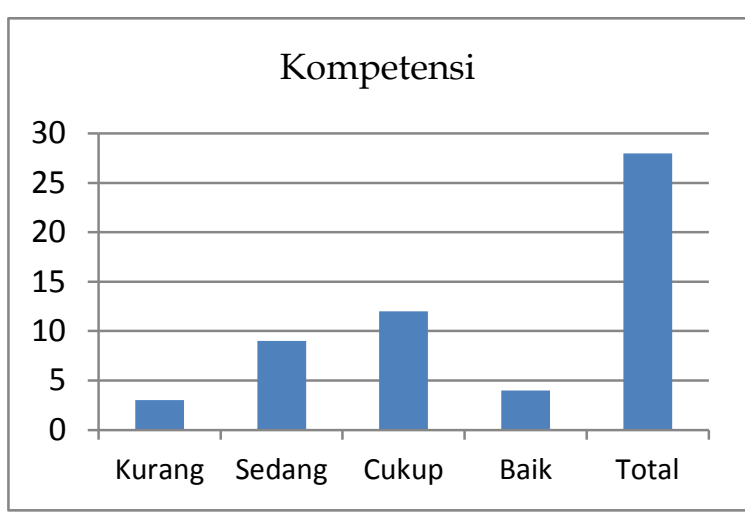

Gambar 1. Kategori Skor Variabel Kompetensi Pedagogik GAK

Kaitan antara latar belakang pendidikan guru dengan kompetensi pedagogik guru Agama Katolik di kabupaten Bantul Pendidikan awal menjadi PNS/pegawai

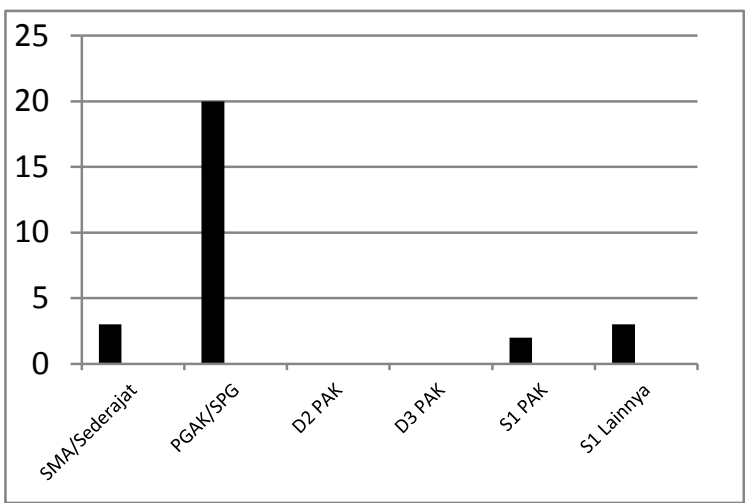

Gambar 2. Pendidikan Awal Menjadi PNS/Pegawai

Dari data tersebut diperoleh gambaran pendidikan awal menjadi PNS/pegawai: dari 28 guru ada 3 orang SMA/sederajat $(10,71 \%), 20$ orang PGAK/SPG (71,42\%), 2 orang S1 PAK $(7,14 \%)$, dan 3 orang S1 (lainnya) $(10,71 \%)$. Jadi guru agama Katolik Sekolah Dasar di Kabupaten Bantul berlatar belakang pendidikan PGAK/SPG ada
20 orang $(71,42 \%)$. Latar belakang pendidikan guru pertama kali menjadi pegawai adalah PGAK atau SPG.

\section{Pendidikan Guru Sekarang}

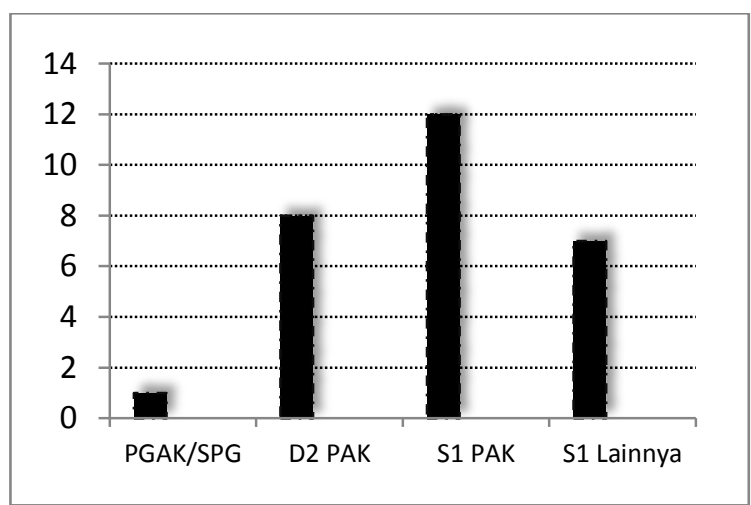

Gambar 3. Pendidikan Guru Sekarang

Dari data tersebut diperoleh gambaran pendidikan guru Agama Katolik Sekolah Dasar Bantul sekarang setelah menjadi PNS/ pegawai: dari 28 guru ada 1 orang PGAK/SPG sederajat (3,57\%), 8 orang D2 PAK $(28,57 \%), 12$ orang S1 PAK $(42,85 \%)$, dan 7 orang S1 (lainnya) (25\%). Jadi guru agama Katolik Sekolah Dasar di Kabupaten Bantul sekarang sudah 19 orang (67,85\%) berlatar belakang pendidikan Strata Satu (S1) pendidikan agama Katolik dan nonpendidikan agama Katolik. Ada kesadaran yang baik dari guru untuk mengembangkan profesinya semaksimal mungkin, walaupun dicapai secara bertahap dari jenjang diploma 2/3 dan sekarang telah S1 walaupun diperoleh dengan tetap melaksanakan tugas mengajar sebagaimana mestinya.

Kaitan Latar Belakang Pendidikan dengan Kompetensi Pedagogik

Tabel 5. Latar Belakang Pendidikan dan Kompetensi Pedagogik

\begin{tabular}{lcc}
\hline $\begin{array}{l}\text { Latar Belakang } \\
\text { Pendidikan }\end{array}$ & F & $\begin{array}{c}\text { Perolehan } \\
\text { Kompetensi }\end{array}$ \\
\hline S1 & 3 & Baik \\
& 8 & Cukup \\
& 8 & Sedang \\
D2 & 3 & Cukup \\
& 4 & Sedang \\
& 1 & Kurang \\
PGAK/SPG & 1 & Cukup \\
\hline
\end{tabular}


Dengan adanya regulasi di bidang pendidikan mendorong guru untuk semakin meningkatkan kualifikasi pendidikannya, guru harus berpendidikan D4 atau S1. Adanya guru yang tidak meningkatkan kualifikasi pendidikannya dikarenakan akan memasuki masa pensiun. Masih ada 8 orang guru yang belum berkualifikasi S1, yaitu 8 orang dengan pendidikan Diploma Dua (D2) tidak melanjutkan sampai ke jenjang S1 karena berada pada usia menjelang pensiun dan 1 orang dengan pendidikan PGAK/SPG tidak dapat melanjutkan pendidikannya bukan karena faktor usia, akan tetapi karena pertimbangan pembiayaan. Lebih memprioritaskan untuk membiayai pendidikan anak, karena guru yang bersangkutan berstatus guru yayasan.

Dari data dijelaskan bahwa walaupun guru berstatus pendidikan S1 tidak dengan sendirinya meningkatkan kompetensi guru. Data menunjukkan dari 4 orang yang kompetensinya baik dengan latar belakang pendidikan PGAK/SPG dan sekarang sudah berpendidikan S1. Dilihat dari latar belakang pendidikan (gambar 4) guru agama Katolik Sekolah Dasar di Bantul yang berijazah S.1 ada 19 orang, dengan perolehan kompetensi pedagogik sebagai berikut: 21, $18,25,24,17,30,26,27,17,29,22,18,19,19$, $23,21,23,20,24$, dengan rata-rata kompetensi pedagogik 423:19 $=22,26$. Sedangkan yang berijazah D.2 ada 8 orang dengan perolehan kompetensi pedagogik sebagai berikut: 20, 25, 13, 19, 18, 24, 24, 19, dengan rata-rata kompetensi pedagogik 162:8= 20,25 dan yang berijazah PGAK/SPG ada 1 orang dengan perolehan kompetensi pedagogik 22. Dengan telah berpendidikan Strata Satu (S.1) belum menunjukkan adanya suatu yang menonjol dilihat dari ratarata kompetensi pedagogik yang dimilikinya.

Dilihat dari latar belakang pendidikan kompetensi pedagogik guru agama Katolik Sekolah Dasar Bantul (Gambar 4) menunjukkan bahwa latar belakang pendidikan S1, D2, maupun PGAK/SPG belum menunjukkan adanya perubahan dan perkembangan kompetensi pedagogik yang menonjol. Dari analisis kaitan antara latar belakang pendidikan dengan kompetensi pedagogik guru agama Katolik, ternyata tidak ada kaitan antara latar belakang pendidikan dengan kompetensi pedagogik guru agama Katolik. Tidak ada kaitan ini telah diuji dengan analisis statistik (korelasi rank Spearman) pada taraf signifikansi $5 \%$, dari perhitungan diperoleh hasil probabilitas/ p.0,298. Dengan demikian tidak ada kaitan antara antara latar belakang pendidikan dengan kompetensi pedagogik guru agama Katolik SD di Kabupaten Bantul.

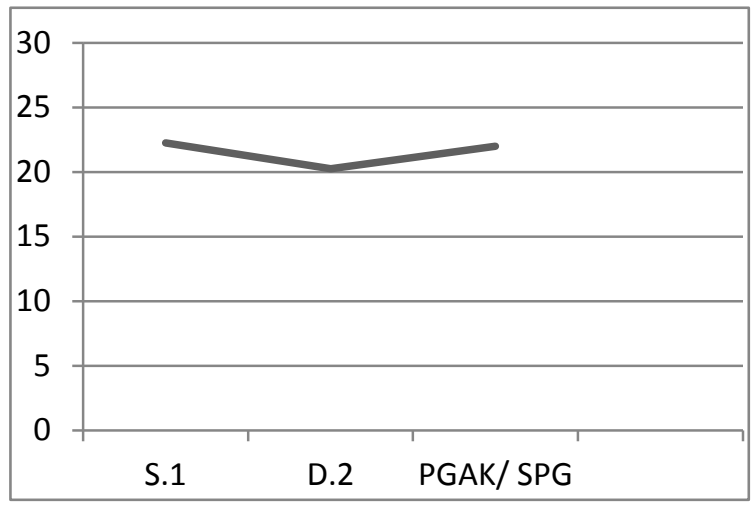

Gambar 4. Latar Belakang Pendidikan dan Kompetensi Pedagogik

Kaitan Antara Masa Kerja menjadi Guru dengan Kompetensi Pedagogik Guru Agama Katolik Sekolah Dasar di Kabupaten Bantul

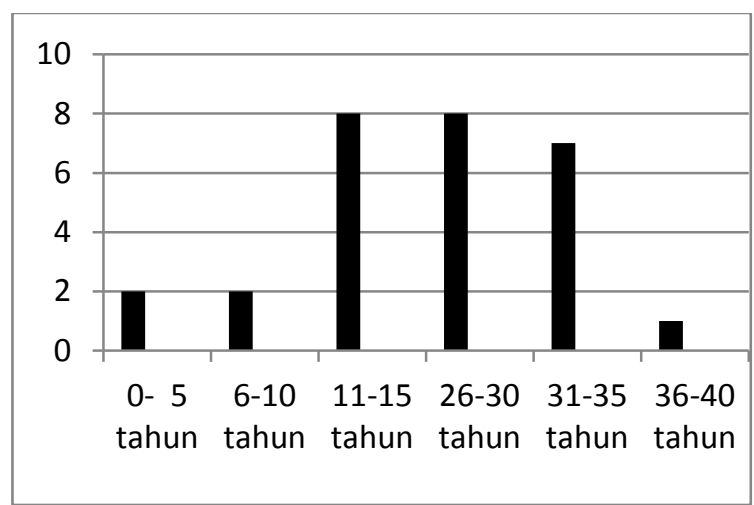

Gambar 5. Masa Kerja Menjadi Guru

Diperoleh gambaran tentang masa kerja menjadi guru agama Katolik: dari 28 guru ada 2 orang masa kerja 0-5 tahun $(7,14 \%), 2$ orang masa kerja 6-10 tahun $(7,14 \%), 8$ orang masa kerja 11-15 tahun $(28,57 \%), 8$ orang masa kerja 26-30 tahun (28,57\%), 7 orang masa kerja 31-35 tahun (25\%), dan 1 orang masa kerja 36-40 tahun 
$(3,57 \%)$. Masa kerja guru berkisar pada 1115 tahun $(28,57 \%), 26-30$ tahun $(28,57 \%)$, dan 31-35 tahun (25\%). Dengan demikian sudah cukup berpengalaman menjadi guru agama Katolik.

Tabel 6. Kaitan Masa Kerja dengan Kompetensi Pedagogik

\begin{tabular}{ccc}
\hline $\begin{array}{c}\text { Masa Kerja } \\
\text { (Tahun) }\end{array}$ & F & $\begin{array}{c}\text { Perolehan Kompetensi } \\
\text { Pedagogik }\end{array}$ \\
\hline 39 & 1 & Sedang \\
\hline 34 & 3 & Cukup \\
\hline 32 & 1 & Cukup \\
& 1 & Sedang \\
\hline 31 & 1 & Sedang \\
& 1 & Kurang \\
\hline 28 & 1 & Sedang \\
& 2 & Cukup \\
& 2 & Baik \\
\hline 26 & 1 & Sedang \\
& 1 & Cukup \\
& 1 & Baik \\
\hline 14 & 2 & Kurang \\
& 2 & Sedang \\
& 2 & Cukup \\
& 1 & Baik \\
\hline 13 & 1 & Sedang \\
\hline 8 & 1 & Cukup \\
\hline 7 & 1 & Sedang \\
\hline 2 & 2 & Cukup \\
\hline
\end{tabular}

Data skor perolehan kompetensi pedagogik guru agama Katolik Sekolah Dasar Bantul berdasarkan masa kerja adalah sebagai berikut: masa kerja 0-5 tahun ada 2 orang dengan kompetensi pedagogik 23 dan 24 dengan rata-rata kompetensi 47:2= 23,5; masa kerja 6-10 tahun ada 2 orang dengan kompetensi pedagogik 22 dan 20 dengan rata-rata kompetensi pedagogik $47: 2=21$; masa kerja 11-15 tahun ada 8 orang dengan kompetensi pedagogik 18, $25,17,27,17,18,19,21$ dengan rata-rata kompetensi pedagogik 162:8 $=20,25$; masa kerja 26-30 tahun ada 8 orang dengan kompetensi pedagogik 21, 20, 25, 24, 30, 26, 29, 18 dengan rata-rata kompetensi pedagogik 193:8= 24,12; masa kerja 31- 35 tahun ada 7 orang dengan kompetensi pedagogik
$13,19,24,22,19,23,24$ dengan rata-rata kompetensi pedagogik $144: 7=20,57$; masa kerja 36-40 tahun ada 1 orang dengan kompetensi pedagogik 19.

Diperoleh gambaran bahwa 57,14\% guru dengan masa kerja antara 26-40 tahun, sehingga cukup berpengalaman menjadi guru agama Katolik. Akan tetapi lamanya masa kerja guru, belum meningkatkan kompetensi pedagogik guru agama Katolik. Atau dengan kata lain lamanya masa kerja menjadi guru belum berkontribusi positif terhadap kompetensi pedagogik guru agama Katolik sekolah dasar di Bantul (Gambar 6). Hal ini ditunjukkan dengan hasil tes yang menunjukkan bahwa ada $75 \%$ guru berada pada kompetensi pedagogik cukup dan sedang. Ada kecenderungan penurunan kompetensi pedagogik dilihat dari masa kerja guru, semakin bertambah masa kerja guru kompetensi pedagogiknya menurun. Masa kerja 26- 30 tahun ada 8 orang guru dengan rata-rata kompetensi pedagogik tertinggi yaitu 24,12 merupakan kompetensi terbaik guru agama Katolik Sekolah Dasar Bantul dilihat dari masa kerja guru. Grafik perkembangan kompetensi pedagogik dilihat dari masa kerja dapat dilihat pada gambar 6 . Hal lain yang juga menarik adalah tidak ada guru agama Katolik Sekolah Dasar di Bantul dengan masa kerja 16-25 tahun, yang berarti selama 10 tahun tidak ada pengangkatan Pegawai Negeri Sipil Pendidikan Agama Katolik Sekolah Dasar di Bantul.

Dari hasil analisis kaitan antara masa kerja menjadi guru dengan kompetensi pedagogik guru agama Katolik ternyata tidak ada kaitan antara masa kerja menjadi guru dengan kompetensi pedagogik guru agama Katolik SD di Kabupaten Bantul (Lampiran 6). Tidak ada kaitan ini telah diuji dengan analisis statistik (korelasi rank Spearman) pada taraf signifikansi $5 \%$. Dari perhitungan diperoleh hasil probabilitas/ p. 0,909 dengan demikian tidak ada kaitan antara masa kerja menjadi guru dengan kompetensi pedagogik guru agama Katolik. Nampak bahwa tidak ada kaitan antara masa kerja dengan kompetensi pedagogik 
guru agama katolik Sekolah Dasar di Kabupaten Bantul. Ada kecenderungan semakin bertambah masa kerja, kompetensi pedagogik semakin menurun.

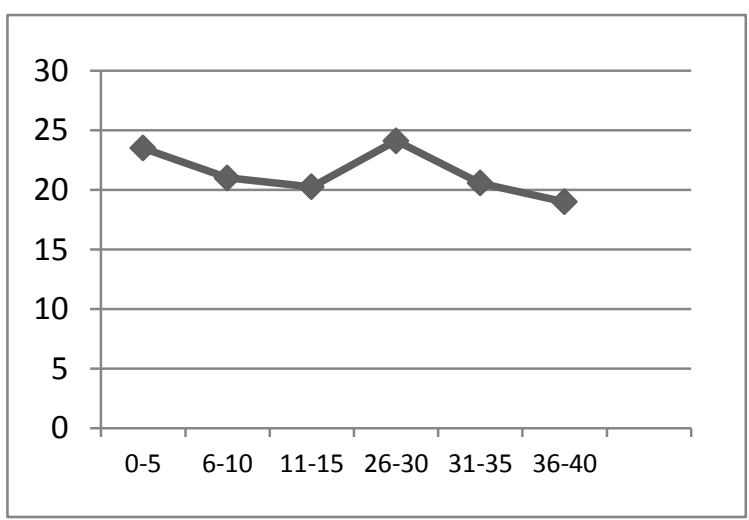

Gambar 6. Kaitan Masa Kerja dengan Kompetensi Pedagogik

Kaitan Pangkat Golongan dengan Kompetensi Pedagogik Guru Agama Katolik Sekolah Dasar di Kabupaten Bantul

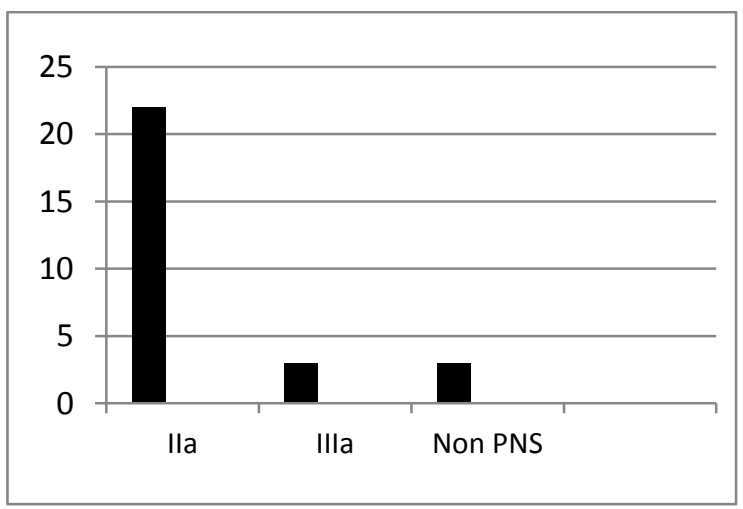

Gambar 7. Pangkat Golongan Pertama Menjadi PNS/ Pegawai

Dari data pada Gambar 7 diperoleh gambaran pangkat golongan pertama menjadi guru agama Katolik: dari 28 guru ada 22 orang dengan pangkat golongan ruang IIa $(71,42 \%), 3$ orang dengan pangkat golongan ruang IIIa $(10,71 \%)$, dan 3 orang non-PNS $(10,71 \%)$. Mayoritas pangkat golongan pertama menjadi PNS/pegawai guru agama Katolik Sekolah Dasar Bantul adalah IIa (71,42 \%). Dengan demikian guru memulai karirnya menjadi guru Agama Katolik dengan latar belakang SPG/SMA sederajat.

Dari data pada Gambar 8 diperoleh gambaran pangkat golongan sekarang setelah menjadi guru agama Katolik: dari 28 guru ada 1 orang dengan pangkat golongan ruang IIIa $(3,57 \%), 6$ orang dengan pangkat golongan ruang IIIb $(21,42 \%), 1$ orang dengan pangkat golongan ruang IIIC $(3,57 \%), 4$ orang dengan pangkat golongan ruang IIId (14,28\%), 13 orang dengan pangkat golongan ruang IVa $(46,42 \%)$, dan 3 orang non PNS (10,71\%). Pengembangan karir guru baru mencapai pangkat golongan ruang tertinggi pada pangkat golongan ruang IVa, yang seharusnya masih dimungkinkan dapat ditingkatkan lagi ke jenjang yang lebih tinggi.

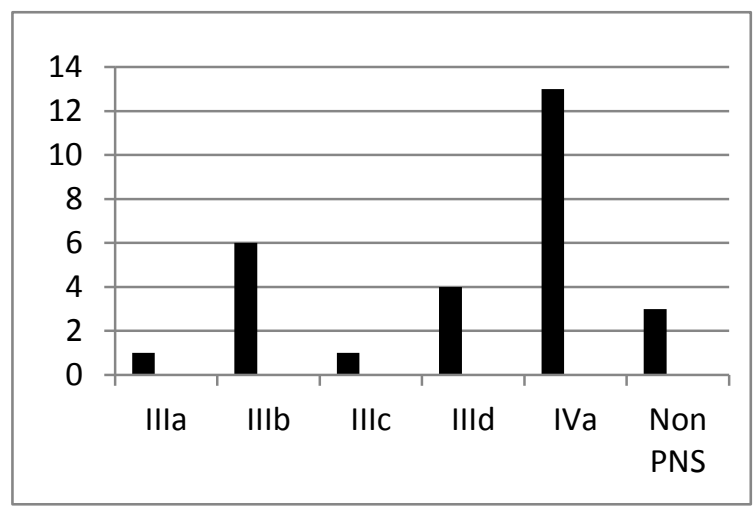

Gambar 8. Pangkat Golongan Sekarang

Kaitan Pangkat Golongan Guru dengan Kompetensi Pedagogik

Tabel 7. Pangkat Guru dan Kompetensi Pedagogik

\begin{tabular}{ccc}
\hline $\begin{array}{c}\text { Jabatan } \\
\text { Guru }\end{array}$ & F & $\begin{array}{c}\text { Perolehan Kompetensi } \\
\text { Pedagogik }\end{array}$ \\
\hline IVa & 5 & Sedang \\
& 5 & Cukup \\
IIId & 2 & Baik \\
& 2 & Kurang \\
& 1 & Cukup \\
IIIc & 1 & Baik \\
IIIb & 1 & Kurang \\
& 1 & Sedang \\
& 1 & Cukup \\
IIIa & 1 & Baik \\
Non PNS & 2 & Cukup \\
& 1 & Cukup \\
\hline
\end{tabular}

Pangkat golongan ruang guru agama Katolik Sekolah Dasar di Bantul pada umumnya dimulai dari pangkat golongan 
ruang IIa $(71,42 \%)$ dan sekarang sudah dengan pangkat golongan ruang IVa (46,42\%). Hal ini menunjukkan bahwa kenaikan pangkat guru pada umumnya berjalan lancar, walaupun ada kecenderungan berhenti pada pangkat dan golongan IVa.

Dilihat dari latar belakang pangkat golongan (Gambar 9) guru agama Katolik Sekolah Dasar di Bantul yang dengan pangkat golongan IIIa ada 1 orang, dengan perolehan kompetensi pedagogik 24; yang dengan pangkat golongan IIIb ada 6 orang dengan perolehan kompetensi pedagogik sebagai berikut: 18, 25, 27, 18, 19, 21 dengan rata-rata kompetensi pedagogik 128:6= 21,33; yang dengan pangkat golongan IIIc ada 1 orang dengan perolehan kompetensi pedagogik 17; yang dengan pangkat golongan IIId ada 4 orang dengan perolehan kompetensi pedagogik: 25, 17, 13, 30 dengan rata-rata kompetensi pedagogik 85:4= 21,25; yang dengan pangkat golongan IVa ada 13 orang dengan perolehan kompetensi pedagogik: 21, 20, 24, 26, 19, 29, 24, 22, $18,19,23,24,19$ dengan rata-rata kompetensi pedagogik 288:13=22,15; guru Non PNS ada 3 orang dengan perolehan kompetensi pedagogik: 23, 22, 20 dengan ratarata kompetensi pedagogik $65: 3=21,66$.

Dengan telah memiliki pangkat golongan IVa belum menunjukkan adanya suatu yang menonjol dilihat dari rata-rata kompetensi pedagogik yang dimilikinya. Tingginya jabatan ruang guru agama Katolik belum menunjukkan bahwa guru yang bersangkutan menjadi lebih kompeten, bahkan ada kecenderungan statis. Grafik perkembangan kompetensi pedagogik dilihat dari latar belakang pangkat golongan dapat dilihat pada gambar 9 berikut.

Dari analisis kaitan antara pangkat golongan guru dengan kompetensi pedagogik guru agama Katolik SD di Kabupaten Kulon Progo (Lampiran 6) ternyata tidak ada kaitan antarapangkat golongan guru dengan kompetensi pedagogik guru agama Katolik SD di KabupatenKulon Progo. Tidak ada kaitan ini telah diuji dengan analisis statistik (korelasi rank Spearman) pada taraf signifikansi 5\%. Dari perhitung- an diperoleh hasil probabilitas/p. 0,744, dengan demikian tidak ada kaitan antara pangkat golongan guru dengan kompetensi pedagogik guru agama Katolik SD di Kabupaten Bantul.

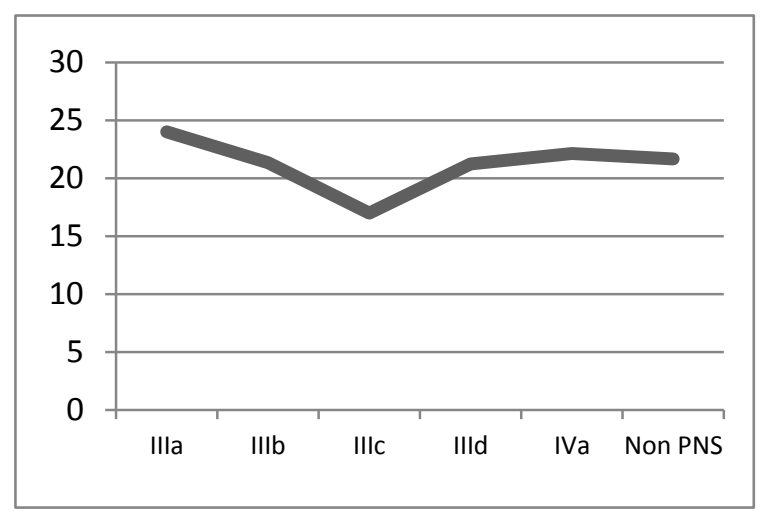

Gambar 9. Pangkat Golongan Guru dan Kompetensi Pedagogik

Kaitan antara Latar Belakang Pendidikan, Masa Kerja, Pangkat Golongan gUru dengan Kompetensi Pedagogik Guru Agama Katolik Sekolah Dasar Kabupaten Bantul

Latar belakang pendidikan guru agama Katolik Sekolah Dasar Bantul dari PGAK/ SPG dan sekarang sudah rata-rata menjadi S1, masa kerja guru agama katolik berkisar antara 11-15 tahun, 26-35 tahun, serta guru agama Katolik diangkat dari pangkat golongan ruang IIa $(71,42 \%)$ dan sekarang sudah dengan pangkat golongan ruang IVa (46,42\%). Latar belakang pendidikan yang sudah rata-rata S1, masa kerja yang relatif sudah lama, golongan ruang guru yang sudah IVa seharusnya berkontribusi positif terhadap kompetensi pedagogik guru agama Katolik Sekolah Dasar di kabupaten Bantul, akan tetapi pada kenyataannya masih dalam kategori kompetensi pedagogik cukup (42,9\%) dan sedang $(32,1 \%)$. Dari analisis statistik (korelasi rank Spearman) menunjukkan bahwa latar belakang pendidikan, masa kerja menjadi guru, golongan ruang menjadi guru agama Katolik tidak ada kaitannya dengan kompetensi pedagogik guru agama Katolik di Kabupaten Bantul.

Deskripsi data penelitian menunjukkan bahwa kompetensi guru agama Katolik Sekolah Dasar di Bantul dikategorikan cukup yaitu $42,9 \%, 12$ orang dari 28 orang 
guru agama Katolik Sekolah Dasar Bantul. Oleh karena itu perlunya strategi membina guru agama Katolik Sekolah Dasar Bantul untuk meningkatkan pengetahuan dan kemampuan guru dalam hal kompetensi pedagogik, terutama yang berkaitan dengan: merancang program pembelajaran, melaksanakan program pembelajaran, evaluasi program pembelajaran. Guru perlu dibina dalam hal pengembangan kompetensi mengajar sehingga anak berkembang secara optimal sesuai dengan taraf perkembangannya. Harus ada kesadaran baru dalam setiap insan guru untuk senantiasa belajar sepanjang hayat, sehingga anak berkembang seturut jamannya, dimana anak hidup secara aktual.

Mayoritas guru agama Katolik Sekolah Dasar di Bantul adalah perempuan, dengan pendidikan awal adalah SPG/ PGAK $(71,42 \%)$, dan sekarang sudah ratarata berpendidikan Strata Satu (S1) $(67,85$ $\%)$. Dengan adanya regulasi dalam dunia pendidikan, dimana guru harus S1 atau D4, kesadaran untuk meningkatkan kualitas diri melalui menempuh studi lanjut sungguh nyata terwujud, ada peningkatan yang cukup dominan.

Deskripsi Data penelitian menunjukkan bahwa guru yang sudah mencapai pendidikan Strata Satu (S1) dengan rerata kompetensi pedagogik 22,26, D2 dengan rerata kompetensi pedagogik 20,25 serta PGAK/SPG dengan rerata kompetensi pedagogik 22. Guru agama Katolik Sekolah Dasar Bantul belum berkontribusi positif terhadap peningkatan kompetensi pedagogik guru agama Katolik Sekolah Dasar di Kabupaten Bantul. Kenaikan pada jenjang pendidikan dari SPG/ PGAK menjadi S1 belum mendorong guru untuk semakin menjadi semakin kompeten terutama dari aspek kompetensi pedagogik.

Guru yang dengan latar belakang S1 belum berkembang secara maksimal, belum berkembang secara optimal kemampuannya, belum didukung dengan kondisikondisi/ iklim kerja yang menantang guru untuk mengembangkan kompetensinya terutama kompetensi pedagogiknya. Perlu ada terobosan sehingga guru yang sudah dengan pendidikan Strata Satu (S1) dimotivasi untuk senantiasa memacu diri sehingga senantiasa mengembangkan budaya mutu misalnya melalui: pelatihan-pelatihan kompetensi guru, studi banding, dan teknologi informasi untuk pembelajaran.

Dari deskripsi data penelitian diperoleh gambaran bahwa dari 28 orang guru ada 15 orang atau $57,14 \%$ dengan masa kerja 26- 35 tahun. Data menunjukkan bahwa guru dengan masa kerja 0-5 tahun ratarata kompetensi pedagogik 23,5 masa kerja 6-10 tahun rata-rata kompetensi pedagogik 21 masa kerja 11-15 tahun rata-rata kompetensi pedagogik 20,25 masa kerja 26-30 tahun rata-rata kompetensi pedagogik 24,12 masa kerja 31-35 tahun rata-rata kompetensi pedagogik 20,57 dan masa kerja 36-40 tahun rata-rata kompetensi pedagogik 19.

Tidak ada yang mencolok rata-rata perolehan kompetensi pedagogik guru agama Katolik Sekolah Dasar di Bantul jika dilihat dari masa kerja. Bertambahnya masa kerja tidak menjamin bahwa kompetensi pedagogiknya bertambah/meningkat. Bahkan ada kecenderungan dengan bertambahnya masa kerja ada penurunan kompetensi pedagogik, yang disebabkan karena kerentanan usia dan sakit. Perlu usaha terus menerus memotivasi guru agar senantiasa mengembangkan kompetensinya, khususnya kompetensi pedagogiknya. Idealnya semakin guru bertambah masa kerjanya juga kecenderungan kompetensi pedagogiknya.

Dari deskripsi data penelitian dapat dijelaskan bahwa pangkat golongan guru agama Katolik Sekolah Dasar di Bantul pada umumnya dimulai dari pangkat golongan ruang IIa $(71,42 \%)$ dan sekarang sudah dengan pangkat golongan ruang IVa $(46,42 \%)$. Hal ini menunjukkan bahwa kenaikan pangkat guru pada umumnya berjalan lancar, walaupun ada kecenderungan berhenti pada pangkat dan golongan IVa.

Tingginya pangkat golongan ruang guru belum meningkatkan kompetensi pedagogik guru agama Katolik Sekolah Dasar di Bantul. Data menunjukkan bahwa guru yang pangkat golongan IIIa rata-rata 
kompetensi 24, guru yang pangkat golongan IIIb rata-rata kompetensi pedagogik 21,33, guru yang pangkat golongan IIIc rata-rata kompetensi pedagogik 17, guru yang pangkat golongan IIId rata-rata kompetensi pedagogik 21,25 guru yang pangkat golongannya IVa rata-rata kompetensi pedagogik 22,15 dan guru Non PNS ratarata kompetensi pedagogik 21,66.

Fakta menunjukkan bahwa guru yang pangkat golongannya IVa berada pada kecenderungan kompetensi pedagogik cukup dan sedang, yang berarti setelah mencapai golongan tersebut stagnan, tidak berkembang. Tidak adanya regulasi yang mengkondisikan guru untuk memacu diri untuk berkembang. Perlunya usaha pembinaan guru terutama yang sudah dengan pangkat golongan IVa sehingga karirnya berkembang secara maksimal. Upayaupaya yang dapat dilakukan misalnya melalui pelatihan penulisan karya ilmiah yang terkait pengembangan profesi.

Latar belakang pendidikan guru, masa kerja guru, pangkat golongan guru belum berkontribusi positif terhadap kompetensi pedagogik guru agama Katolik Sekolah Dasar di Bantul. Latar belakang pendidikan, lamanya masa kerja guru, dan tingginya pangkat golongan guru belum memberikan gambaran tingginya kompetensi pedagogik guru agama Katolik Sekolah Dasar di Kabupaten Bantul. Ada kecenderungan bahwa guru berada dalam fase aman menjadi guru sehingga tidak muncul kreativitas terutama untuk mengembangkan kompetensinya.

Upaya yang dapat dilakukan adalah dengan pembinaan pengembangan profesi guru secara berkelanjutan. Guru perlu dikondisikan untuk menjadi agen perubahan dengan mengembangkan budaya belajar, belajar sepanjang hayat, belajar seumur hidup. Guru harus membiasakan diri membaca buku dan mempergunakan teknologi informasi untuk menambah wawasan serta pengembangan pembelajaran. Guru harus menyadari bahwa sumber belajar murid bukan satu-satunya dari guru di sekolah, melainkan anak dapat belajar dari pelbagai sumber belajar yang ada disekitarnya.
Latar belakang pendidikan guru, masa kerja guru, pangkat golongan guru belum berkontribusi positif terhadap kompetensi pedagogik guru agama Katolik Sekolah Dasar di Bantul. Latar belakang pendidikan, lamanya masa kerja guru, dan tingginya pangkat golongan guru belum memberikan gambaran tingginya kompetensi pedagogik guru agama Katolik Sekolah Dasar di Kabupaten Bantul.

Castetter (Fattah, 1996, pp.20-21) menyebutkan faktor-faktor yang menyebabkan tidak efektifnya penampilan kerja sebagai berikut: (1) yang bersumber dari individu itu sendiri: kelemahan intelektual, kelemahan psikologis, kelemahan fisiologis, demotivasi, faktor personalitas, keusangan dan ketuaan, preparasi posisi, orientasi nilai; (2) yang bersumber dari dalam organisasi: sistem organisasi, peranan organisasi, kelompok-kelompok dalam organisasi, perilaku yang berhubungan dengan pengawasan, iklim organisasi; (3) yang bersumber dari lingkungan ekternal organisasi: keluarga, kondisi ekonomi, kondisi hukum, nilai-nilai sosial, peranan kerja, perubahan teknologi, perkumpulanperkumpulan.

Memperbandingkan antara fakta lapangan dengan teori tersebut, disimpulkan: ada faktor-faktor lain selain latar belakang pendidikan, masa kerja, pangkat golongan guru yang mempengaruhi kompetensi guru. Memperkembangkan kompetensi pedagogik guru harus mempertimbangkan aspek-aspek seperti yang dikemukakan Castetter.

\section{Simpulan dan Saran}

\section{Simpulan}

Berdasarkan analisis data dan pembahasan hasil penelitian dapat disimpulkan sebagai berikut: (1) Kompetensi pedagogik guru agama Katolik Sekolah Dasar di Kabupaten Bantul dalam kategori cukup. Data menunjukkan 42,9\% guru agama Katolik Sekolah Dasar di Bantul memiliki kompetensi pedagogik kategori cukup. Kategori sedang 32,1\%, kategori Baik 14,3\%, dan kategori kurang 10,7\%; (2) pendidikan 
awal adalah SPG/ PGAK (71,42\%), dan sebagian besar berada pada usia 46-60 tahun. Adanya regulasi dalam dunia pendidikan, kesadaran untuk meningkatkan kualitas diri melalui menempuh studi lanjut sungguh nyata terwujud. Guru yang sudah berpendidikan S1 ada 19 orang dari 28 orang guru (67,85\%). Akan tetapi dari deskripsi data penelitian menunjukkan bahwa latar belakang pendidikan belum berkontribusi positif terhadap peningkatan kompetensi pedagogik guru agama Katolik Sekolah Dasar di Kabupaten Bantul; (3) masa kerja guru berada diantara 26-35 tahun. Masa kerja guru yang relatif lama, belum berkontribusi positif terhadap kompetensi pedagogik guru agama Katolik Sekolah Dasar di Bantul. Guru yang masa kerjanya lebih lama belum menunjukkan kompetensi pedagogiknya lebih baik. (4) pangkat golongan ruang guru agama Katolik Sekolah Dasar di Bantul pada umumnya dimulai dari pangkat golongan ruang IIa $(71,42 \%)$ dan sekarang sudah dengan pangkat golongan ruang IVa $(46,42$ $\%$ ). Hal ini menunjukkan bahwa kenaikan pangkat guru pada umumnya berjalan lancar, walaupun ada kecenderungan berhenti pada pangkat dan golongan IVa. Tingginya pangkat golongan ruang guru belum dengan sendirinya menjamin kompetensi pedagogik guru agama Katolik Sekolah Dasar di Bantul tinggi; (5) latar belakang pendidikan, masa kerja, pangkat golongan guru belum berkontribusi positif terhadap kompetensi pedagogik guru agama Katolik Sekolah Dasar di Bantul. Latar belakang pendidikan, lamanya masa kerja guru, dan tingginya pangkat golongan guru belum memberikan gambaran tingginya kompetensi pedagogik guru agama Katolik Sekolah Dasar di Kabupaten Bantul.

Berdasarkan temuan penelitian tentang kompetensi pedagogik guru agama Katolik Sekolah Dasar di Kabupaten Bantul yang masuk dalam kategori cukup implikasinya kompetensi pedagogik guru agama Katolik harus semakin ditingkatkan. Peningkatan kegiatan pelatihan pembelajaran dan penguasaan teknologi informasi akan semakin menambah kemampuan pedagogik guru agama Katolik Sekolah Dasar di Bantul. Hal-hal seperti ini merupakan tanggung jawab bersama antara pihak sekolah dan instansi yang terkait.

Berdasarkan temuan penelitian tentang profil guru agama Katolik Sekolah Dasar di Kabupaten Bantul ditemukan bahwa masa kerja guru rata-rata 26-35 tahun dengan usia antara 46-60 tahun, implikasinya adalah perlu dipikirkan adanya regenerasi untuk mengantisipasi adanya guru yang akan pensiun/purnabakti. Peningkatan kegiatan pelatihan pembelajaran dan penguasaan teknologi informasi akan semakin menambah kemampuan pedagogik guru agama Katolik sekolah dasar di Bantul. Hal-hal seperti ini merupakan tanggung jawab bersama antara pihak sekolah dan instansi yang terkait.

Pelaksanaan penelitian ini telah diupayakan semaksimal mungkin agar sesuai dengan tujuan penelitian, tetapi masih terdapat keterbatasan dan kelemahan yang tidak dapat terhindarkan antara lain: (1) pengumpulan data dalam penelitian ini hanya didasarkan hasil isian angket dan tes oleh guru agama Katolik Sekolah Dasar di Bantul dalam waktu yang relatif singkat, sehingga dimungkinkan adanya sikap kurang obyektif dalam proses pengisian. Sikap tersebut antara lain keengganan, kelelahan, dan ketidakjujuran dalam pengisian angket. Pengungkapan kompetensi pedagogik guru pada dasarnya dapat dilakukan dengan berbagai metode pengungkapan kompetensi pedagogik guru, sehingga penelitian belum mampu mengungkapkan kompetensi pedagogik guru secara mendalam; (2) populasi data penelitian yang diambil relatif kecil sehingga kemungkinan kesalahan dalam pengambilan kesimpulan relatif lebih besar.

Saran

Pertama, sehubungan dengan kompetensi pedagogik guru yang masih cukup dan sedang, pemerintah dan atau pihakpihak yang berkewenangan diharapkan lebih memperhatikan guru sebagai sebuah asset yang perlu dijaga dan dikembangkan, 
melalui kursus-kursus atau pelatihan-pelatihan yang mengembangkan kompetensi pedagogik guru. Pengembangan kompetensi yang berkaitan dengan: pemahaman dan pengembangan peserta didik, merancang program pembelajaran, pelaksanaan program pembelajaran, serta evaluasi program pembelajaran. Program sertifikasi guru yang mengedepankan pengembangan kompetensi guru harus terus dilanjutkan dan ditingkatkan sebagai tanda penghargaan terhadap setiap guru yang berkualitas dan kompeten. Kedua, berdasarkan hasil penelitian tentang kompetensi pedagogik guru agama Katolik Sekolah Dasar di Kabupaten Bantul yang dikaitkan dengan latar belakang pendidikan, masa kerja serta pangkat golongan perlu ada upaya dari berbagai pihak pemangku kepentingan baik Pemerintah maupun Gereja Katolik untuk mencari solusi pemecahan terhadap masih rendahnya kompetensi pedagogik guru agama Katolik.

\section{Daftar Pustaka}

Balitbang Depdiknas. (2010). Data guru layak mengajar. Jakarta: Depdiknas.

Fattah, N. (1996). Landasan manajemen pendidikan. Bandung: P.T. Remaja Rosdakarya

Fernandes, H. J. X. (1984). Evaluation of educational program. Jakarta: National Education Planning, Evaluation and Curriculum Development.
Hamsah. (2007). Profesi kependidikan. Jakarta: Bumi Aksara .

Konferensi Waligereja Indonesia. (2005). Pedoman gereja katolik Indonesia. Jakarta: SMK Grafika Mardi Yuwana Bogor.

Mardapi. (2008). Teknik penyusunan instrumen. Yogyakarta: Mitra Cendekia Press.

Menpan dan Reformasi Birokrasi RI. (2009). Jabatan fungsional guru dan angka kreditnya. Jakarta: Kementerian PAN \& RB.

Prasaja. (2009). Ternyata Guru Masih Dibutuhkan di Bantul. Prasaja. Web.id. Jurnal Kependidikan. Di download tanggal 30 -11-2014.

Republik Indonesia. (2003). Undang Undang RI No. 20, Tahun 2003, tentang Sistem Pendidikan Nasional.

Republik Indonesia. (2005). Undang Undang RI No. 14, Tahun 2005, tentang Guru dan Dosen.

Sudarwan. (2002). Inovasi pendidikan. Bandung: CV Pustaka Setia.

Sugiyono. (2006). Metode penelitian pendidikan. Bandung: Alfabeta.

Sugiyono. (2010). Statistika untuk penelitian. Bandung: Alfabeta. 